\title{
Remote Sensing and GIS for the Spatio-Temporal Change Analysis of the East and the West River Bank Erosion and Accretion of Jamuna River (1995-2015), Bangladesh
}

\author{
Md Arafat Hassan ${ }^{1 *}$, Suriya Jesmine Ratna1, Masud Hassan², Sonia Tamanna ${ }^{3}$ \\ ${ }^{1}$ Department of Geography and Environment, University of Dhaka, Dhaka, Bangladesh \\ ${ }^{2}$ Department of Soil, Water, and Environment, University of Dhaka, Dhaka, Bangladesh \\ ${ }^{3}$ Chittagong University of Engineering and Technology, Chittagong, Bangladesh \\ Email: *mh20457@email.vccs.edu, jesminesuriya@gmail.com, masudhassanswe1112@gmail.com, \\ sonia.tamanna123@gmail.com
}

How to cite this paper: Hassan, M.A., Ratna, S.J., Hassan, M. and Tamanna, S. (2017) Remote Sensing and GIS for the Spatio-Temporal Change Analysis of the East and the West River Bank Erosion and Accretion of Jamuna River (1995-2015), Bangladesh. Journal of Geoscience and Environment Protection, 5, 79-92. https://doi.org/10.4236/gep.2017.59006

Received: June 13, 2017

Accepted: August 22, 2017

Published: August 25, 2017

Copyright $\odot 2017$ by authors and Scientific Research Publishing Inc. This work is licensed under the Creative Commons Attribution International License (CC BY 4.0).

http://creativecommons.org/licenses/by/4.0/

\begin{abstract}
Jamuna River is one of the principal rivers of Bangladesh, changing continuously due to erosion and accretion over the past decades. This analysis evaluates the East Bank and the West Bank erosion and accretion between 1996 and 2015 for Jamuna River. An unsupervised classification algorithm and post-classification change employing skills in Geographic Information System are performed to evaluate spatial and temporal dynamics of erosion and accretion for different points of Jamuna River using Bangladesh. Landsat image $(1995,2005,2015)$. The correctness of the Landsat-produced map ranges from $82 \%$ to $84 \%$. It has been evidently observed that changes in the proportion of erosion and accretion differ in different points of Jamuna River. The highest eroded area is 3.82 square kilometers $\left(\mathrm{km}^{2}\right)$ during the period of 1995 to 2005 and the highest accreted area is 6.15 square kilometers $\left(\mathrm{km}^{2}\right)$ during the period of 1995 to 2015. The erosion and accretion values fluctuated from place to place. The changing trend of Riverbank is creating many socio-economic problems in the proximate areas.
\end{abstract}

\section{Keywords}

Remote Sensing, GIS, River Erosion, Accretion, Change Analysis, Jamuna River

\section{Introduction}

In Bangladesh, natural streams of water of fairly large size, flowing in a diverging 
and converging channels, are divided into three main rivers. The river Jamuna is one of them. The Old Brahmaputra goes down with the name "Jamuna", and it is the largest braided river that crosses through the low-lying subsided deltaic floodplain of Bangladesh [1]. It is the cardinal channel in a braided stream of Brahmaputra river as the circulation commencing from India to Bangladesh. Tibetan plateau is the growth center of the Jamuna River, and 93\% drainage of the river lays peripheral to Bangladesh. It merges with the Padma River approaching Goalundo Ghat when flowing south. Then combining with Meghna River near Chandpur, it flows down towards the Bay of Bengal (The study area of Jamuna River in Figure 1). After flowing about $2740 \mathrm{~km}$ from its origin and $220 \mathrm{~km}$ from the northern borders of Bangladesh, the Jamuna interacts with the Ganges, then the Meghna and at last flows into the Bay of Bengal [1]. Jamuna is one of the oldest rivers which has a generation about of almost 250 years [2]. Since the beginning of that time period, the Jamuna River has maintained state way, mostly disconnected by small islands or called "chor". Changeable banks and instantaneous rates at edgeways movement characterize Jamuna's braided plan which is the accumulative result of different outflows of water and sediments. Resulting from river bank Erosion, surrounding areas like Tista floodplain soils nutrients status are also modulating under several condition like Tista barrage, water dynamics, water flow rate and fertility status of these zones [3] [4]. Millions of people have been dislocated from their original living places because of acute riverbank erosion in Bangladesh. 283 places, 85 cities, and outgrowth enter including $2004 \mathrm{~km}$ of riverbank line are vulnerable to erosion in Bangladesh [5]. The fourth IPCC (Intergovernmental Panel on Climate change) report anticipates that the monsoon rainfall of South Asia will increase highly which will create increasing flow in the rivers. This increased flow will reduce the flood control capacity resulting in the increased bank erosion [6]. The Jamuna is provided to have exquisite bank erosion and highest rate of bank line movement [7]. The future water ability of Jamuna River will be affected by the running climate change through altering the precipitation pattern. Enhancement of flow has been affected by the Jamuna River over the past years. Future water discharge on Jamuna River will increase with massive rain in the catchment area of the river on the enhancement level with the highest amount of snowmelt because of running global warming situation [8].

The Jamuna is showing adventurous and violent behavior by its bank erosion rate [9] [10]. The erosion has significant impact on differential population change on rotated human occupancy and bank line settlements of displaces. The Jamuna River is characterized with various types and size of bars, mega forms and macro forms of a bar from the hierarchical bed from classification [11].

From 1994-1998, $5.63 \mathrm{~km}$ long Bangabanndhu bridge was constructed to connect the east and west side of the Jamuna river. Due to water regulation in Jamuna River before 1996, the rate of channel shifting increased in SirajganjBhuyiapur region. The water flow also changed during 1988 \& 1998 due to flood and heavy monsoon rain [2]. 


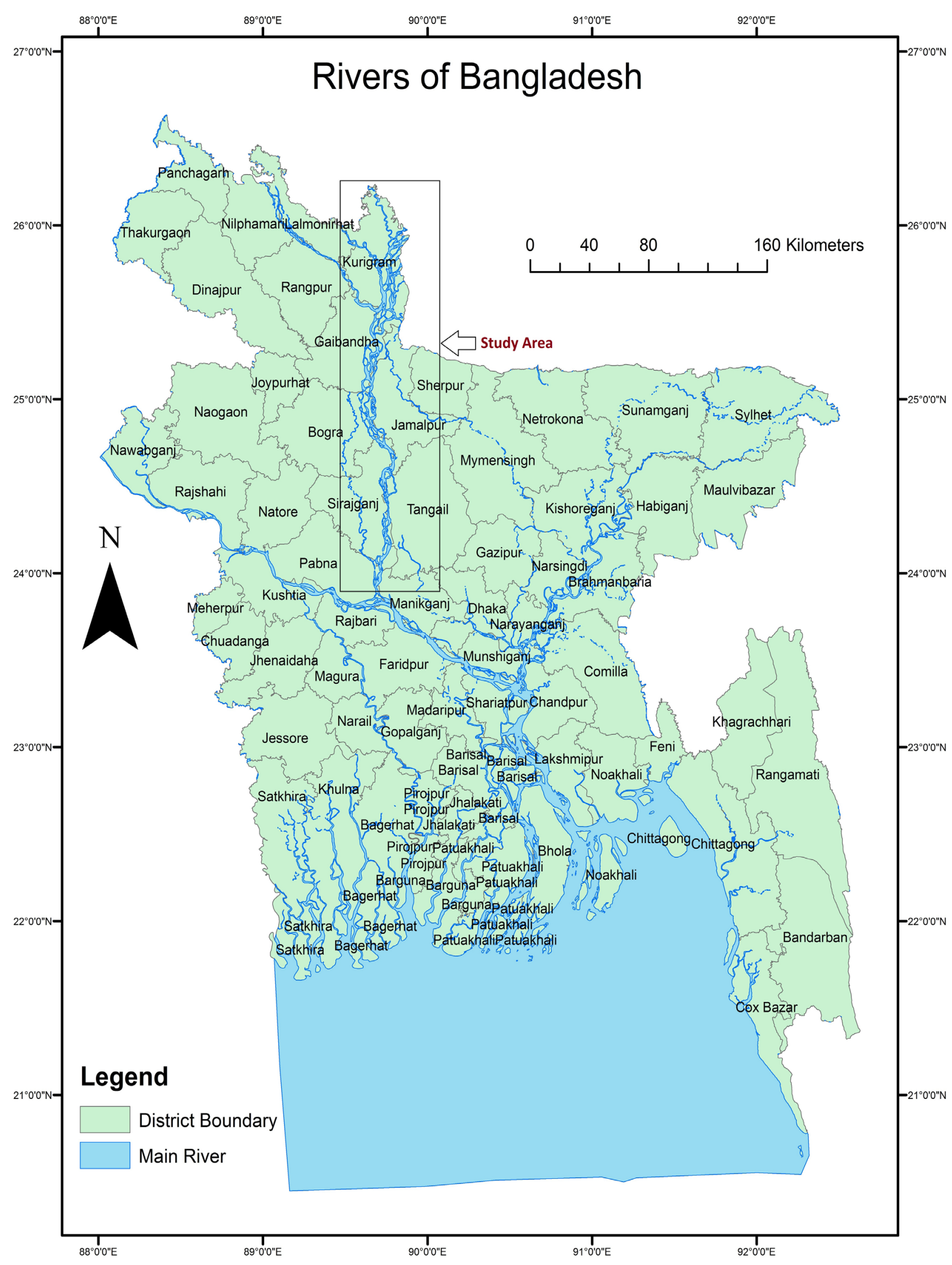

Figure 1. Study area (Jamuna River). 
There is no recognizable trend of channel movement observed for the Jamuna. Continuous learning is triggered to explain the struggle of the Jamuna from the Brahmaputra. Previous studies of different aspects of Jamuna River have investigated the changing nature related to erosion and accretion. Pahlowar and Hossain (2015) studied water discharge data of Brahmaputra River to establish a relationship with accretion and dynamics of erosion for various time intervals along with average annual water discharge. Sarkar [12] mentioned that the Brahmaputra River is characterized with continuous bank erosion driving to channel pattern changes and shifting of bank line. It also quantified the actual bank erosion or deposition along the Brahmaputra River. Archana and Nayan determined the river dynamics of Brahmaputra River located in India through RS.GIS based assessment [13]. Uddin, Shrestha, and Alam made a measurement of morphological alteration and vulnerability of river bank erosion edgeways of the Jamuna using remote sensing [14].

This work primarily aims to use remote sensing and GIS to evaluate spatial and temporal changes of the East and the West bank of Jamuna River between the year of 1995 to 2015, such as assessing shifting of the banks through bank line analysis besides the erosion-accretion measurement. Remote sensing (RS) data, collected at defined intermissions, are immensely suitable and model to assess and for observing riverbank shifting and erosion. The change analysis of the bank line is important to predict the changing path of the River and to take steps to cope up with the changing nature of the River. By assessing the changing pattern of the bank line, it could predict if the bank line shifting could be the position for life and environment. This work is also significant to visualize different spatial range of Jamuna. Through some of these objectives, this work can provide some insights into its impact on the physical and social environment in the surrounding area.

\section{Methodology}

\subsection{Data and Software Used}

For observing and juxtaposing erosion and accretion changes of the west and east bank of Jamuna River, Landsat TM image of 1995 and 2005, and Landsat OLI image of 2015 (Path 138 and Row $42 \& 43$ ) shown in Figures 2-4 respectively have been used. Seven reflective Bands for 1995 and 2005 and eleven reflective bands for 2015 have been considered for image classification. Images depict dry time of Jamuna River as those were collected between December to April.

The change analysis has been accomplished under the structure of RS and GIS. The processing task of images has been executed using ERDAS image processing tool. GIS analysis has been executed by using ArcGIS 10.2.1.

\subsection{Data Processing Analysis}

Three images of Jamuna River of 1995, 2005 \& 2015 were downloaded from United States of Geological Survey (USGS) website (in Figures 2-4). Seven layers 


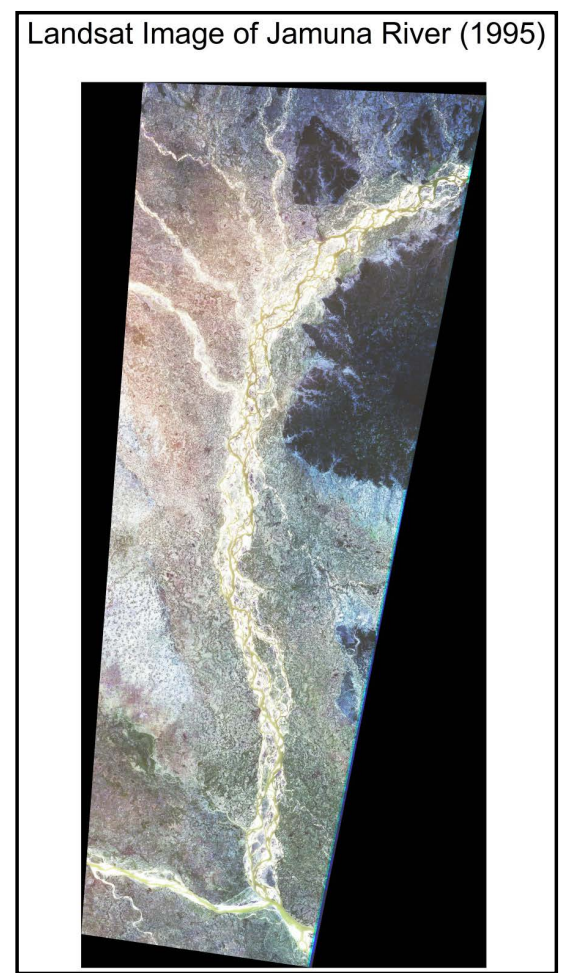

Figure 2. Landsat images of Jamuna River in 1995.

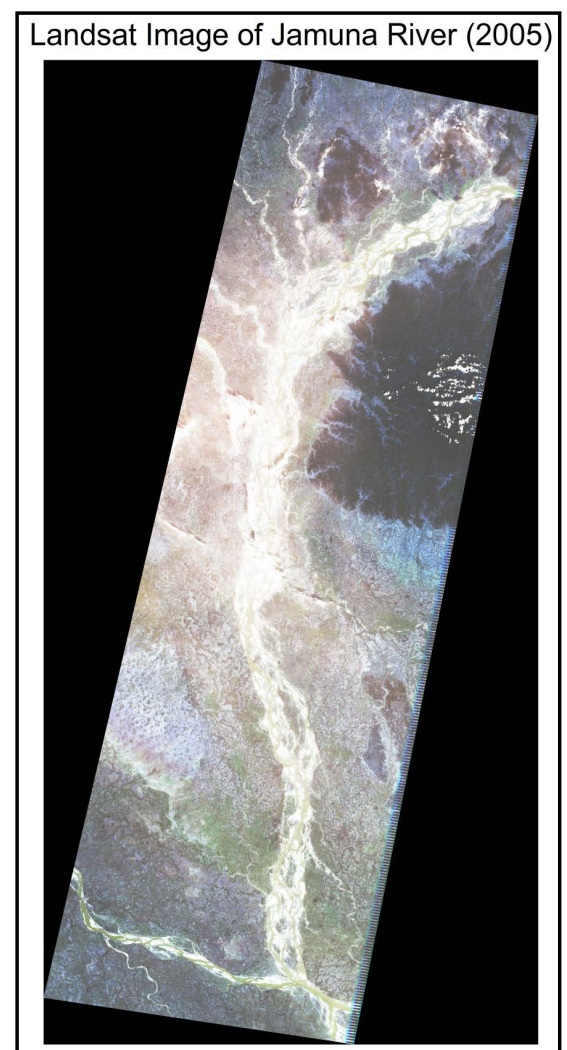

Figure 3. Landsat images of Jamuna River in 2005 . 


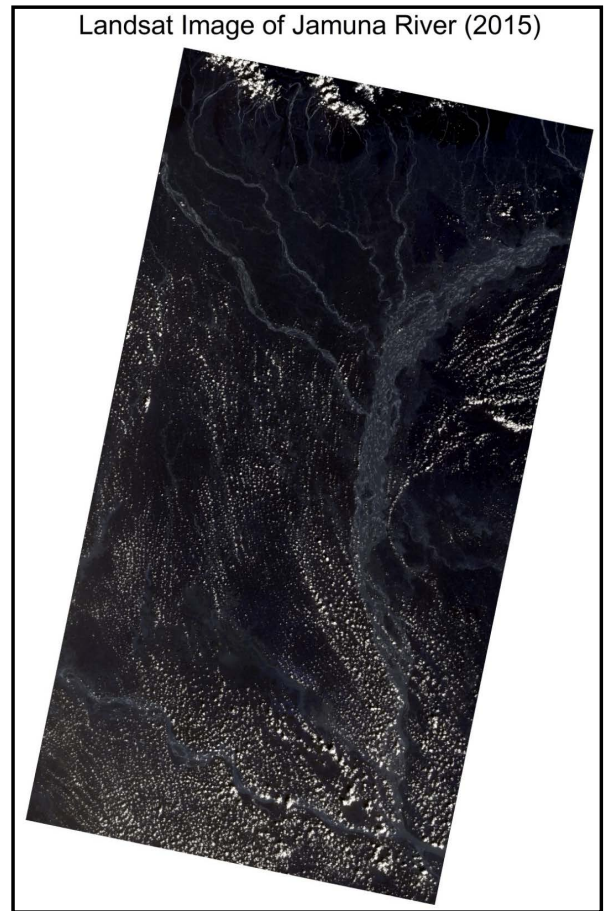

Figure 4. Landsat images of Jamuna River in 2015.

of the images were stacked from the landsat images of 1995 and 2005 and eleven layers from lasndsat image of 2015 to visualize the overall scenery of the Jamuna river banks. Once rectified, the two rows of each path of Landsat image of each year were mosaicked. The study area was distinguished through subset tool of Erdas Imagine software. The images was analyzed through histogram equalization, supervised, unsupervised and NDVI classification. Histogram equalization algorithm were used to enhance the quality of the downloaded cloud-free Landsat images. Supervised, unsupervised and NDVI classification of the Jamuna river was done to distinguish the water and land feature or obviously to say to demarcate the river line/bank from the water. Among the three classifications of supervised, unsupervised and NDVI, unsupervised classification of the Jamuna River was selected to analyze the changes as this classification gave an explicit scene of the water and land feature. There were made 10 classes of the land and water body in this classification to depict all types of these features. Three shape files of each year were created from the histogram equalized unsupervised Landsat images using ArcGIS 10.2.1 through manual digitization to extract river boundaries and to measure the distance of the east and west bank of Jamuna River to find out the dynamic changes of the last twenty years' period. The histogram equalized unsupervised classified image of 1995 was considered as the base map and the histogram equalized unsupervised classified images of 2005 and 2015 were examined to calculate the east and west bank line movement of each segment over those years. Conceptual Data Processing and Analysis are shown in Figure 5. 


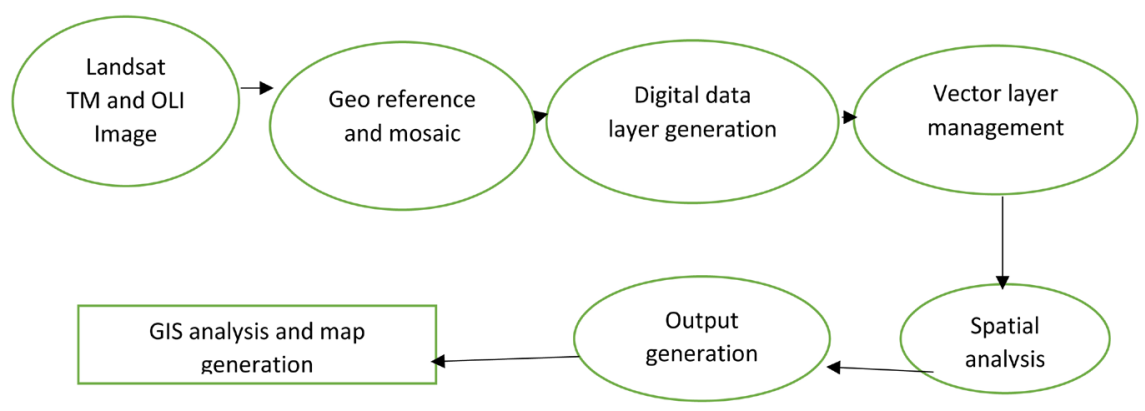

Figure 5. Conceptual framework.

Area of interest (AOI), a GIS tool has been used for visual data analysis. Reference data was corroborated for saving these. Therefore, they depict real classes.

70 ground samples were collected using Global Positioning System (GPS) to detect pixels on the image on a ground map. This work was carried out using Magellan Triton 300 Handheld GPS. GIS technique was performed to overlay GPS information to calculate classification accuracy. Confusion matrix along with error of omission \& error of commission [15] was performed for reliability measurement. In general, reliability was $82 \%$ to $84 \%$.

By performing these skills, the result was calculated using an unsupervised algorithm with Maximum likelihood technique which improved the outcome.

\section{Result and Discussion}

The Riverbank line has been identified and established at Landsat image of 1995, 2005, and 2015. Histogram Equalized unsupervised image is meaningful for identifying the Riverbank line. By analyzing three distinct Landsat image from 1995 to 2015, it was observed the five-year rate of erosion and accretion of the active channel of Jamuna River. The highest eroded area is 3.81 square kilometers $\left(\mathrm{km}^{2}\right)$ in the period of 1995 to 2005 and the highest accreted area is 6.15 square kilometers $\left(\mathrm{km}^{2}\right)$ in the period of 1995 to 2015. Changes of Jamuna River bank erosion (1995-2005) is shown in Figure 6. The erosion and accretion values fluctuated from place to place. The fluctuation of erosion and accretion on the west bank and east bank can be shown on a graph as Figure 6.

It is prominent that the highest erosion amount on the west bank from 1995 to 2005 was about 3.81 square kilometers $\left(\mathrm{km}^{2}\right)$ when accretion amount was 5.62 square kilometers $\left(\mathrm{km}^{2}\right)$. On the east bank, the highest amount of erosion was about 2.61 square kilometers $\left(\mathrm{km}^{2}\right)$ when accretion amount was $2.26 \mathrm{~km}$. So, there are more visible new bank line formation on the west side of the river over this period. The highest erosion amount on west bank from 1995 to 2015 was about 1.99 square kilometers $\left(\mathrm{km}^{2}\right)$ when accretion amount was $9.14 \mathrm{~km}$. On the east bank, the highest amount of erosion was about 3.63 square kilometers $\left(\mathrm{km}^{2}\right)$ when accretion amount was $1.59 \mathrm{~km}$. Therefor, there is bank shifting from the east side to west due to huge accretion rate on the west bank on these years. The fluctuation of the amount of erosion and accretion on the west bank and east bank can be shown on a graph in Figure 7. 


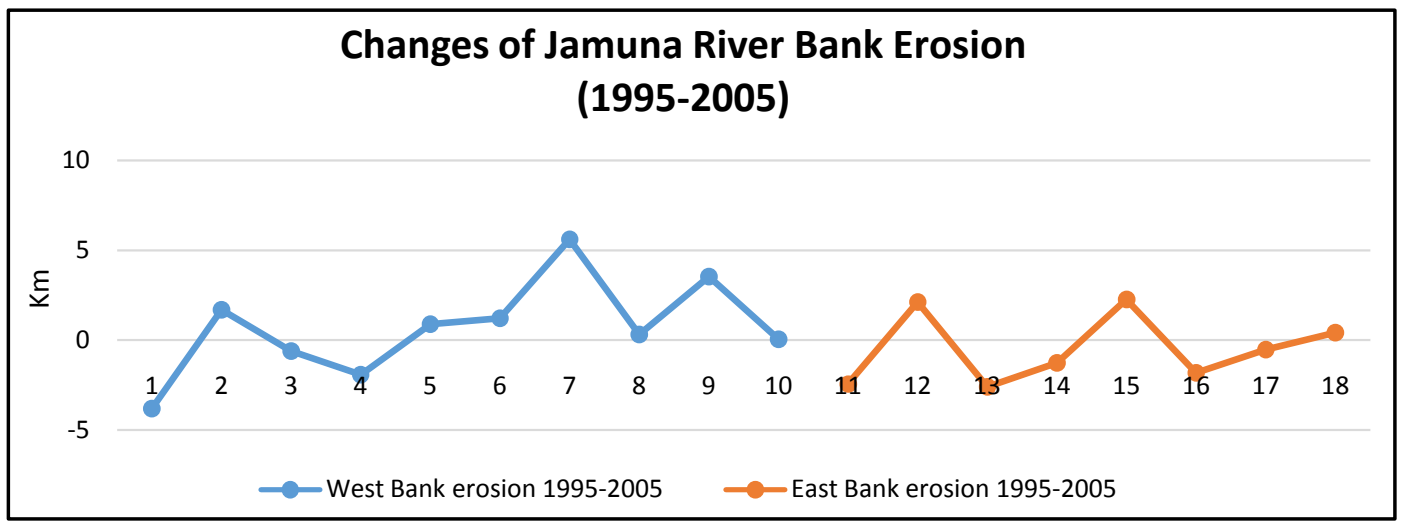

Figure 6. Changes of Jamuna River bank erosion (1995-2005).

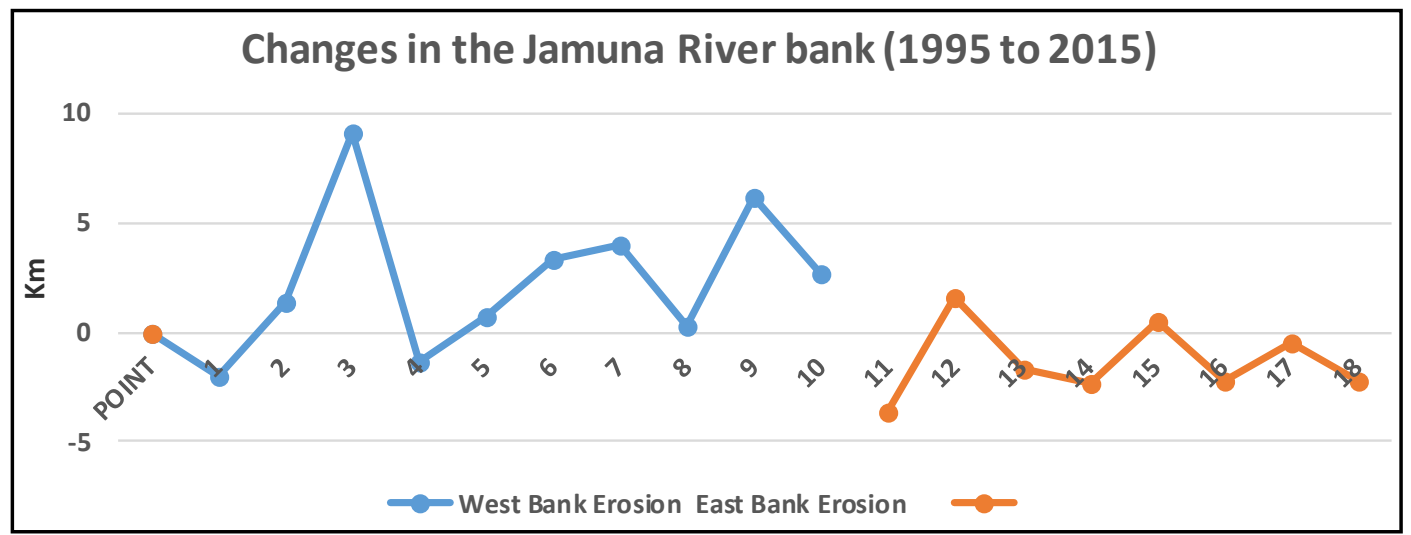

Figure 7. Changes in Jamuna River bank (1995 to 2015).

As the accretion rate of the west bank is higher than the erosion rate and the erosion rate is higher on the east bank of Jamuna River than the accretion rate, so the course of the River has been shifted towards west direction through this period.

It has been identified that the highest erosion amount on west bank from 1995 to 2005 was about 3.81 square kilometers $\left(\mathrm{km}^{2}\right)$ when accretion amount was 5.62 $\mathrm{km}$. On the east bank, the highest amount of erosion was about 2.61 square kilometers $\left(\mathrm{km}^{2}\right)$ when accretion amount was $2.26 \mathrm{~km}$ (in Figure 8). The highest erosion amount on west bank from 1995 to 2015 (in Figure 9) was about 1.99 square kilometers $\left(\mathrm{km}^{2}\right)$ when accretion amount was $9.14 \mathrm{~km}$. On the east bank, the highest amount of erosion was about 3.63 square kilometers $\left(\mathrm{km}^{2}\right)$ when accretion amount was $1.59 \mathrm{~km}$. The complete table and graph of the fluctuations of the amount of erosion and accretion on the west bank and east bank from 1995 to 2015 has been shown in Figure 8 .

As shown in Figure 9, the accretion amount of the West Bank of Jamuna River was higher from 1995 to 2015 than from 1995 to 2005 . On the other hand, the erosion amount of the west bank was higher from 1995 to 2005 than from 1995 to 2015 .

The graph of the changes of Jamuna River east bank represents the higher 


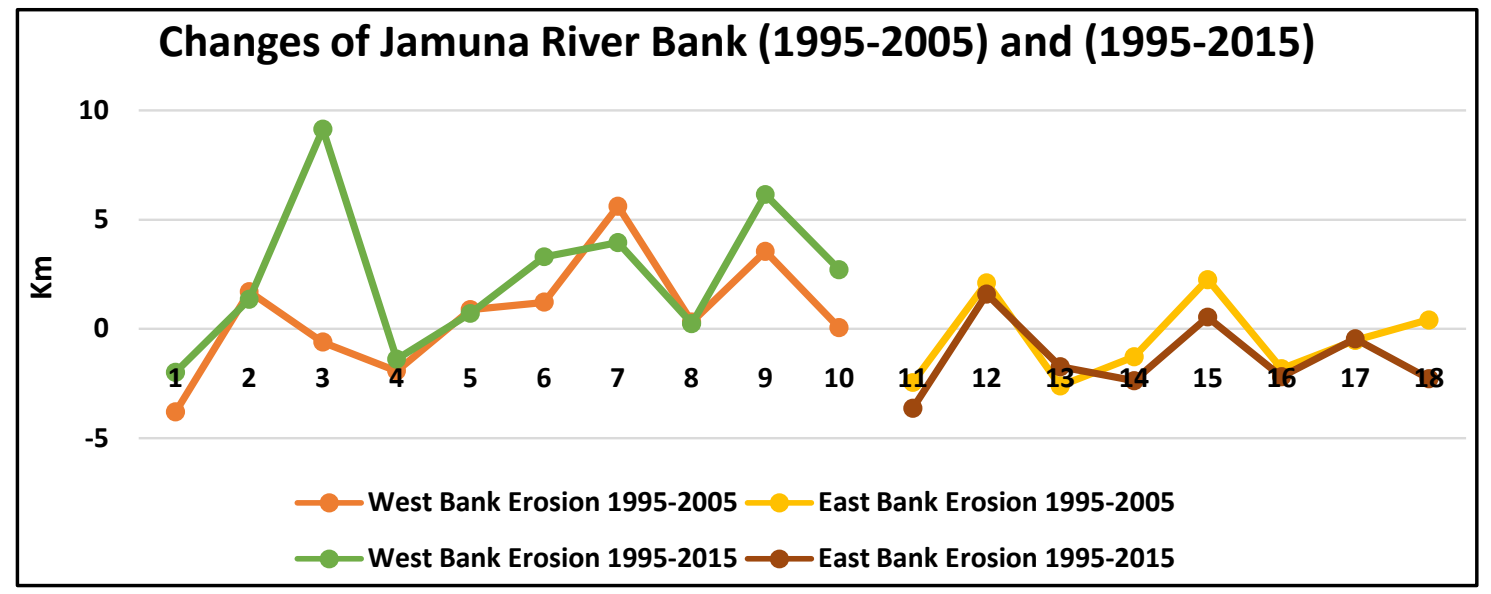

Figure 8. Changes of Jamuna River (1995-2005) and (1995-2015).

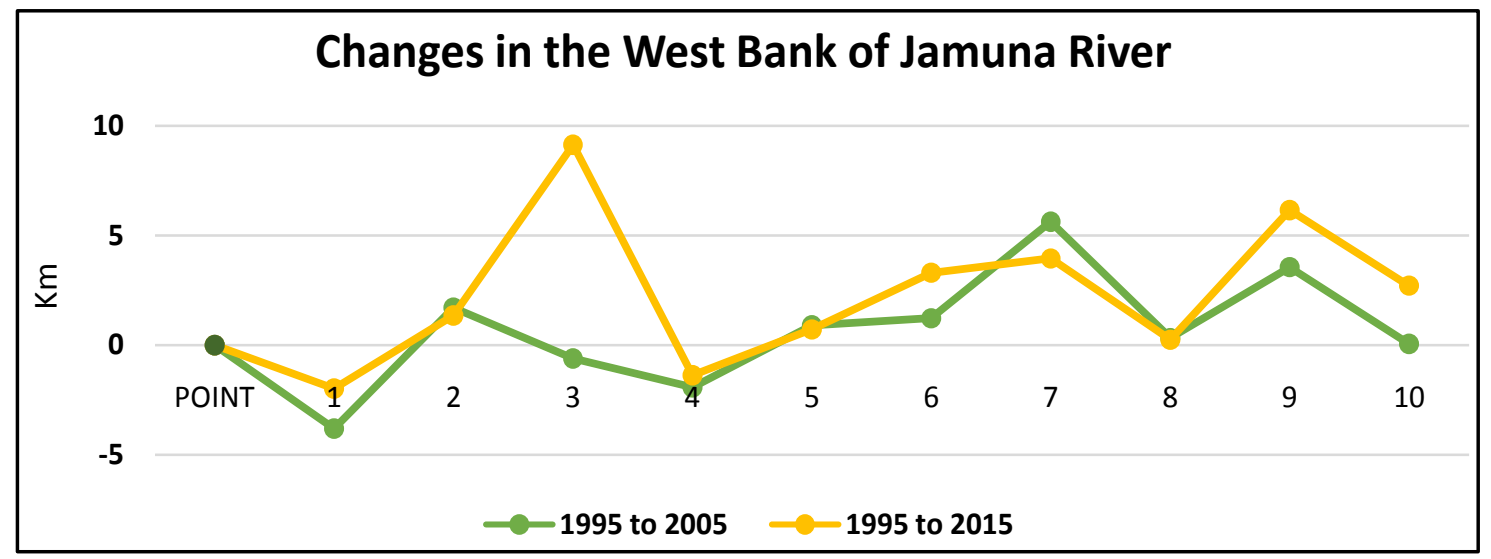

Figure 9. Changes in the west bank of Jamuna River (1995 to 2005) and (1995-2015).

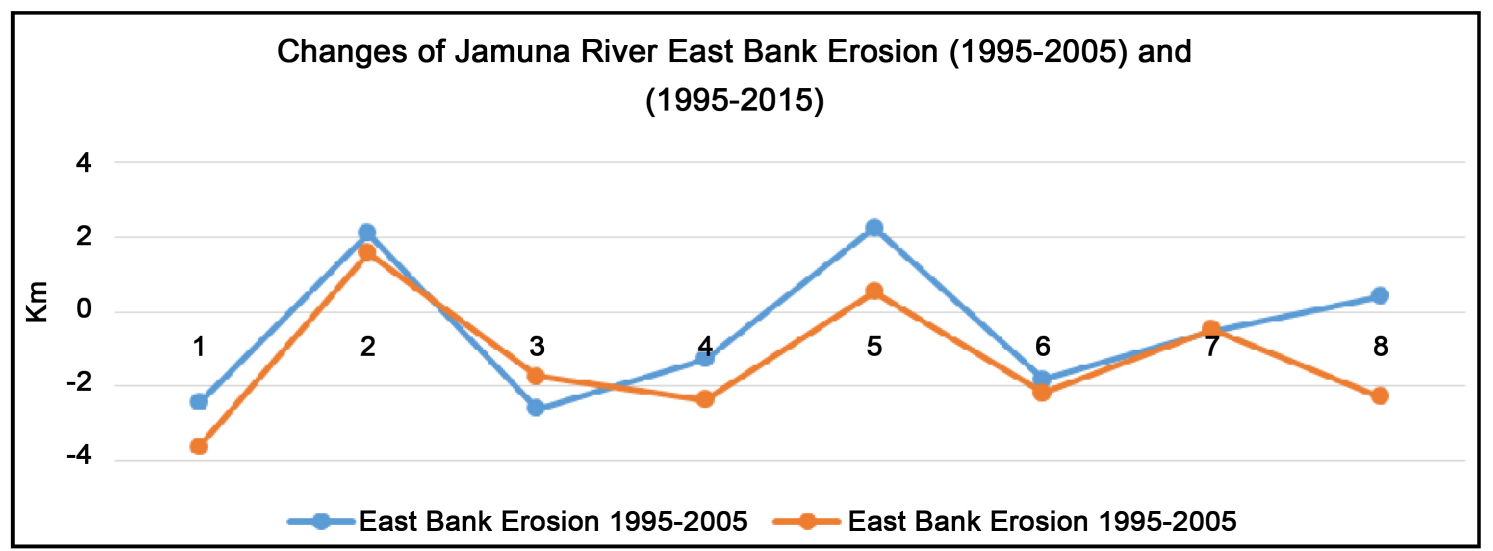

Figure 10. Changes in the east bank of Jamuna River (1995 to 2005) and (1995-2015).

accretion amount from 1995 to 2005 than from 1995 to 2015. Besides, the erosion amount was also higher from 1995 to 2005 than from 1995 to 2015 (Figure 10). The shape maps of Jamuna River of 1995, 2005 and 2015 have been given below respectively (in Figures 11-13) and the changes has been detected with the overlapping representation of the maps. 


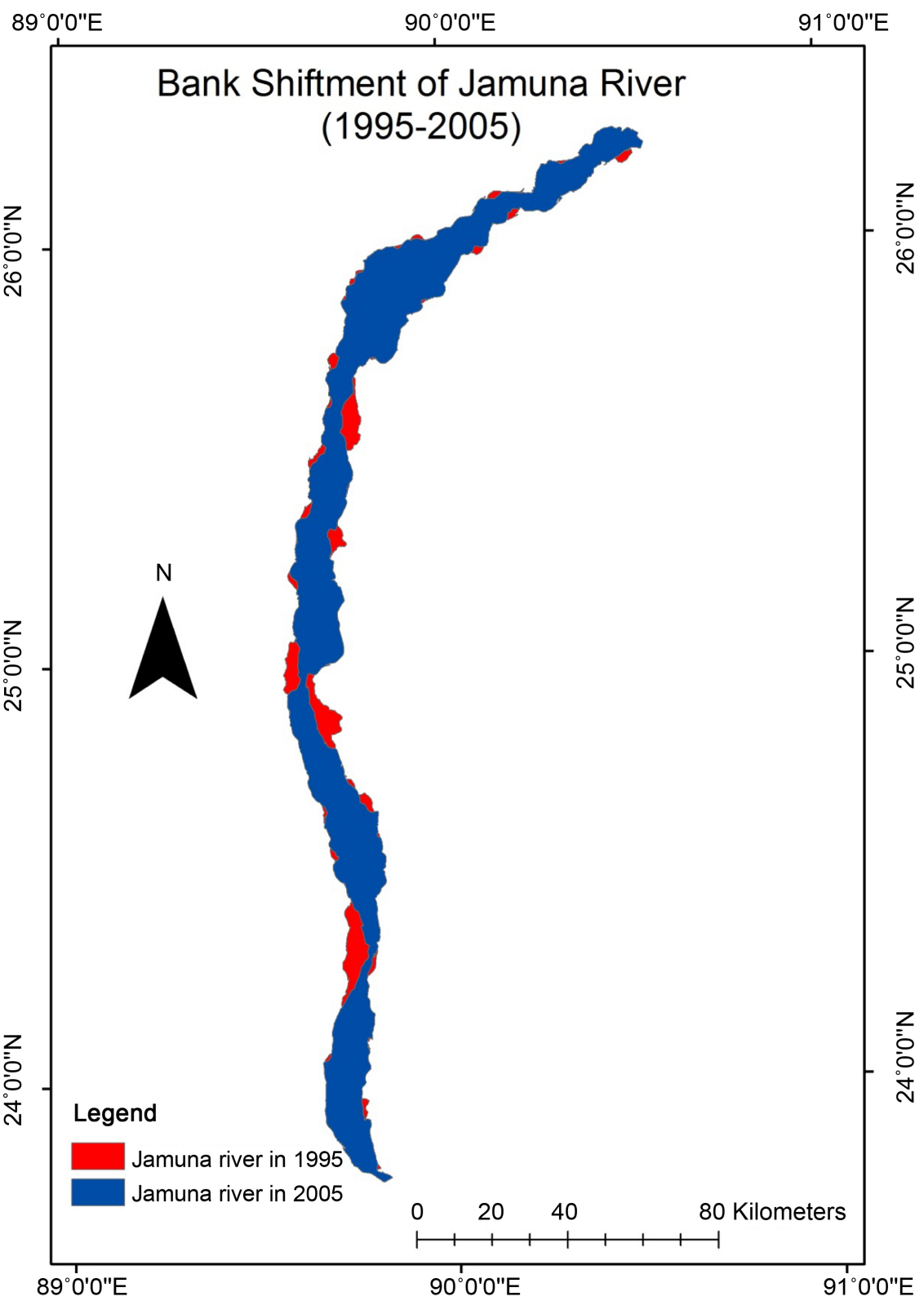

Figure 11. Changes of the east and west Jamuna river bank (1995-2005) due to the correlation of erosion and accretion of bank line.

\section{Socio Economic Impact of Jamuna River Erosion}

The mighty 127 miles long Jamuna River has eroded almost 30 villages in the past 10 years [16]. The consequence of the erosion is not only human displacement but also continuous erosion destroys roads and other communication facilities reducing the chance of getting reliefs quickly. The affected people, who have no other choices, at first, try to copy locally and then migrate to the nearby cities for livelihood and start to live in slums, in the open space on both sides of rail lines or in Govt Khash Lands of the cities [17]. Each year, the area of the slum in several cities is increasing and most of the people have come here due to river erosion [6]. The condition of social amenities, such as food, shelter, em- 


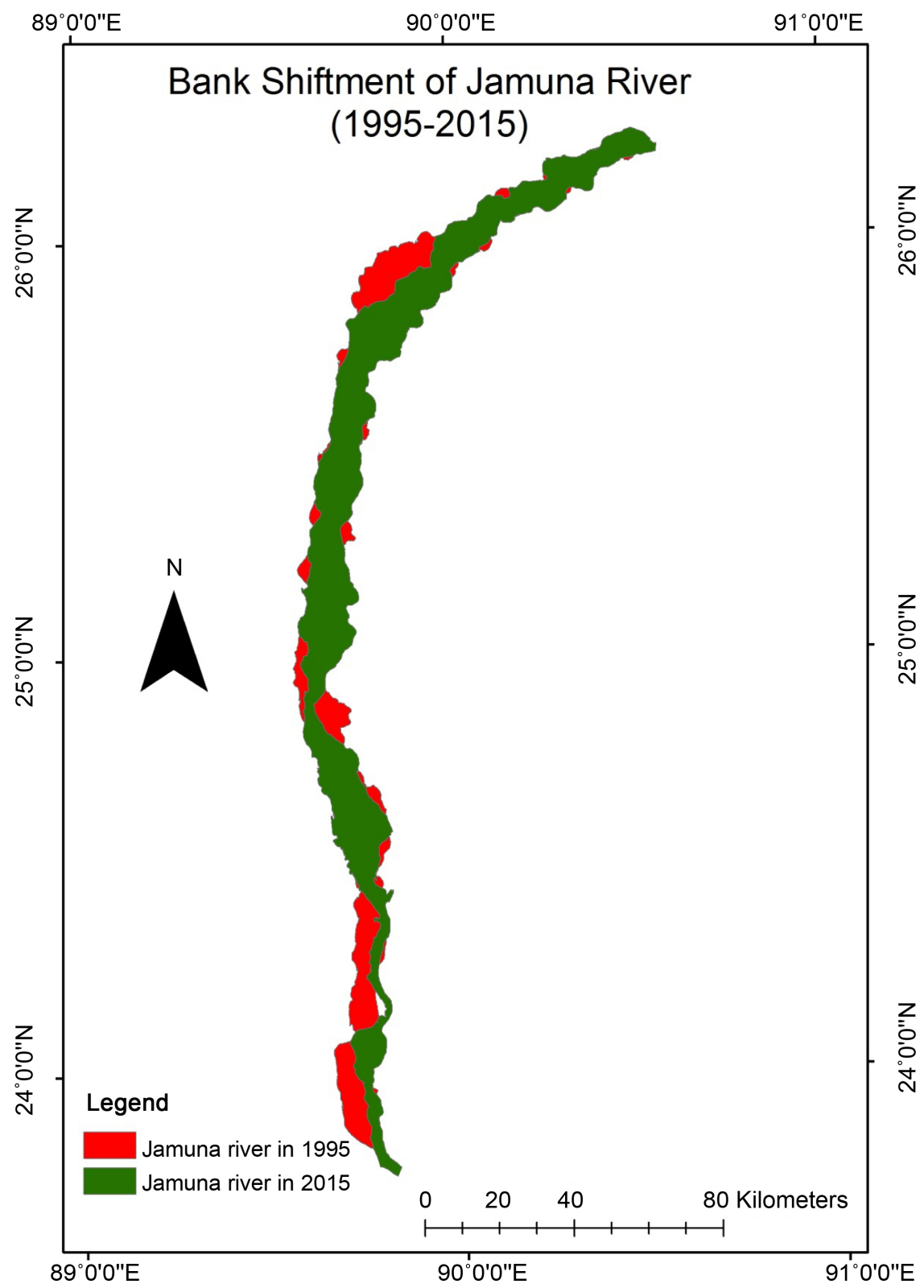

Figure 12. Changes of the east and west Jamuna river bank (1995-2015) due to the correlation of erosion and accretion of bank line.

ployment and health care facilities are very deficient in these slums. The affected people are mostly unskilled, illiterate and those unemployed people increase the number of slum dwellers. As a result, poverty aggravation is increasing day by day [18].

\section{Conclusion}

In general, it has been observed that the riverbank shifting of Jamuna occurs continuously each year. This continuous river bank erosion and accretion process cause land loss and land formation. A comparative study by Ashraf Dewan, 2017 on river Gangas between two period 1989-1995 and 2000-2005 shows that 


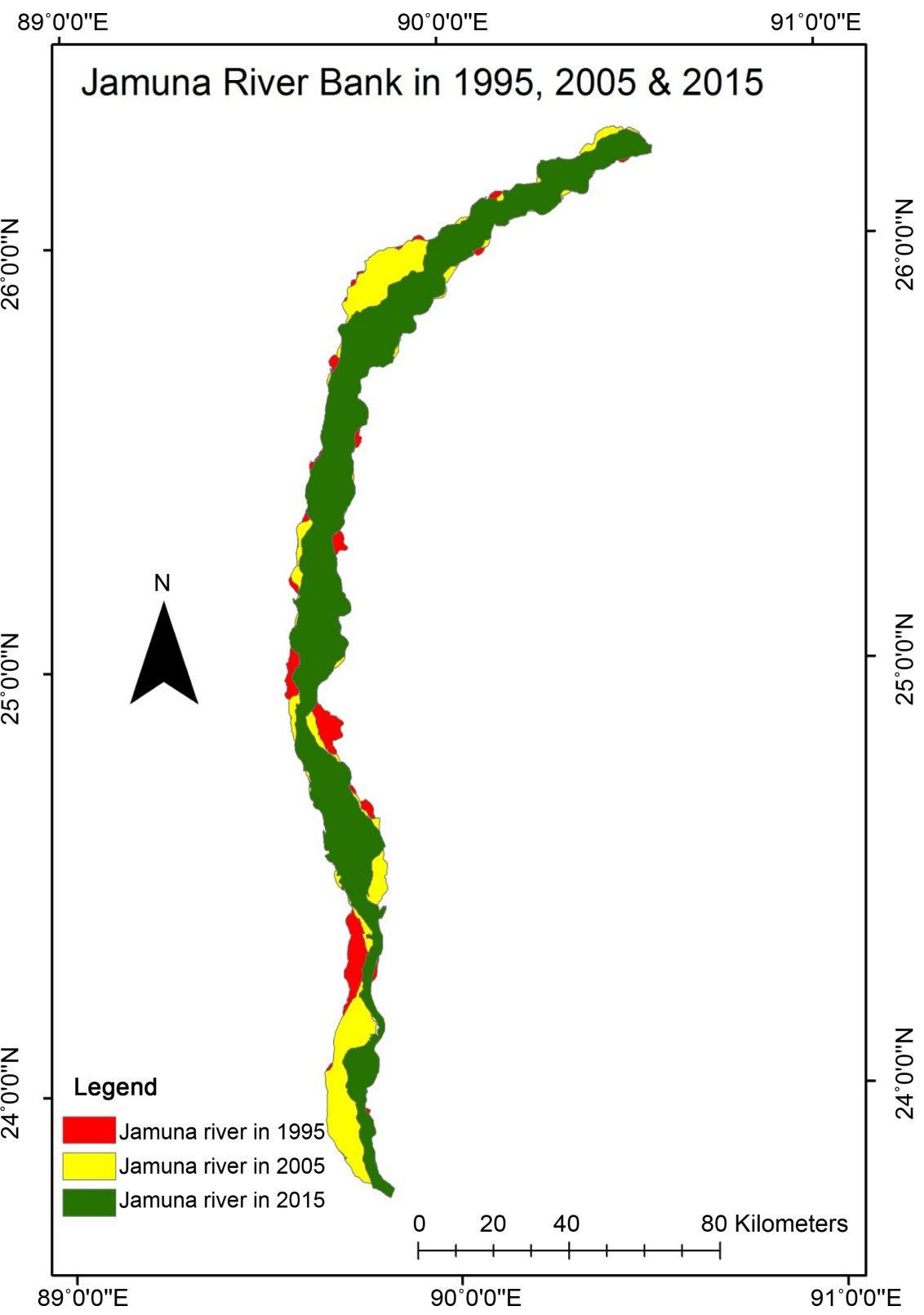

Figure 13. Changes of the east and west Jamuna River bank (1995, 2005 \& 2015) due to the correlation of erosion and accretion of bank line.

with the increase of river bank accretion rate from 170 in 1995 to 183 in 2005, the erosion rate changed from $58.1 \%$ to $54.9 \%$ [19]. This study has also manifested the effective use of geospatial data and advantage of riverbank mapping. The study result can be a base for further analysis for future consideration of long-term erosion protection measures in the Jamuna. The result can be made more precise by considering Char lands and with higher resolution professional geospatial data. The identified area can be a valuable source for the expertise to find the optimum place for causeway to protect the river bank. The analysis and the result found from this research can be a model for similar studies on another riverbank management system in Bangladesh. The raster image analysis result 
can be compared with other river studies to get a comparative idea of rate of river bank erosion. The result drawn by this study can explain the rapid morphological changes in the riverbank under current climate change situation.

\section{Acknowledgements}

Our most humble and sincere thanks to Lecturer Mallik Sezan Mahmud for his direction but mainly for his endless motivation. Demure gratitude to USGS and other online sources. I am continuing thanking my mom and beloved younger brother Durjoy, for instinct love and support. Last but not least, I am great full to my extraordinary friend, for her tolerance and vitality as I am maudlin and without her all things become pointless and descend into chaos.

\section{References}

[1] Ashworth, P.J. (1996) Mid-Channel Bar Growth and Its Relationship to Local Flow Strength and Direction. Earth Surface Processes and Landforms, 21, 123. https://doi.org/10.1002/(SICI)1096-9837(199602)21:2<103::AID-ESP569>3.0.CO;2-O

[2] Bhuiyan, M.A., Kumamoto, T., Julleh Jalalur, M. and Shigeyuki, S. (2010) Regulation of Brahmaputra-Jamuna River around Jamuna Bridge Site, Bangladesh: Geoenvironmental Impacts. Journal of Water Resource and Protection.

[3] Hassan, M., Hassan, R., Pia, H.I., Hassan, M.A., Ratna, S.J. and Aktar, M. Variation of Soil Fertility with Diverse Hill Soils of Chittagong Hill Tracts, Bangladesh.

[4] Hassan, M., Ahmed, A.A.S., Hassan, M.A., Nasrin, R., Rayhan, A.B.M.S., Salehin, S.M.U. and Rahman, M.K. (2017) Changes of Soil Fertility Status in Some Soil Series of Tista Floodplain Soils of Bangladesh, during 1996-2016. Asian Research Journal of Agriculture (ARJA), 5, 1-9. https://doi.org/10.9734/ARJA/2017/34365

[5] Islam, M.F. and Rashid, A.B. (2011) Riverbank Erosion Displacees in Bangladesh: Need for Institutional Response and Policy Intervention. Bangladesh Journal of Bioethics, 2, 4-19.

[6] Rahman, M.U., Jahan, S. and Kamal, M.M. (2010) Response of Climate Change on the Morphological Behavior of the Major River System. Institute of Water Modelling.

[7] Khan, N.I. and Islam, A. (2003) Quantification of Erosion Patterns in the Brahmaputra-Jamuna River Using Geographical Information System and Remote Sensing Techniques. Hydrological Processes, 17, 959-966. https://doi.org/10.1002/hyp.1173

[8] Rajib, M.A., Rahman, M.M. and McBean, E.A. (2011) Application of Regional Climate Model Simulation and Flow Data for Assessing Future Water Availability in the River Jamuna. International Journal of Environmental Sciences, 1, 884-896.

[9] Coleman, J.M. (1969) Brahmaputra River: Channel Processes and Sedimentation. Sedimentary Geology, 3, 129-239. https://doi.org/10.1016/0037-0738(69)90010-4

[10] Klaassen, G.J. and Masselink, G. (1992) Planform Changes of a Braided River with Fine Sand as Bed and Bank Material.

[11] Jackson, R.G. (1975) Hierarchical Attributes and a Unifying Model of Bed Forms Composed of Cohesionless Material and Produced by Shearing Flow. Geological Society of America Bulletin, 86, 1523-1533. https://doi.org/10.1130/0016-7606(1975)86<1523:HAAAUM>2.0.CO;2

[12] Sarkar, A., Garg, R.D. and Sharma, N. (2012) RS-GIS Based Assessment of River Dynamics of Brahmaputra River in India. Journal of Water Resource and Protec- 
tion, 4, 63-72. https://doi.org/10.4236/jwarp.2012.42008

[13] Archana, S. and Nayan, S. (2012) RS-GIS Based Assessment of River Dynamics of Brahmaputra River in India. Journal of Water Resource and Protection, 4, Article ID: 17423 .

[14] Uddin, K., Shrestha, B. and Alam, M.S. (2011) Assessment of Morphological Changes and Vulnerability of River Bank Erosion alongside the River Jamuna Using Remote Sensing. Journal of Earth Science and Engineering, 1, 30-35.

[15] Lillesand, T.M. and Kiefer, R.W. (2001) Remote Sensing and City. Integrated Water Flow Model (IWFM) Bangladesh University of Engineering \& Technology (BUET) Dhaka.

[16] Shetu, M.S.R., Islam, M.A., Rahman, K.M.M. and Anisuzzaman, M. (2017) Population Displacement Due to River Erosion in Sirajganj District: Impact on Food Security and Socio-Economic Status. Journal of the Bangladesh Agricultural University, 14, 191-199. https://doi.org/10.3329/jbau.v14i2.32694

[17] Mahbubur Rahman, M., Hassan, M.S., Bahauddin, K., KhondokerRatul, A. and Hossain Bhuiyan, M.A. (2017) Exploring the Impact of Rural-Urban Migration on Urban Land Use and Land Cover: A Case of Dhaka City, Bangladesh. Migration and Development, 1-18. https://doi.org/10.1080/21632324.2017.1301298

[18] Elahi, K.M. (1989) Population Displacement Due to River Bank Erosion of the Jamuna in Bangladesh. In: Clarke, J.I., et al., Eds., Population and Disaster, Basil Blackwell, Oxford, 81-97.

[19] Dewan, A., Corner, R., Saleem, A., Rahman, M.M., Haider, M.R., Rahman, M.M. and Sarker M.H. (2017) Assessing Channel Changes of the Ganges-Padma River System in Bangladesh Using Landsat and Hydrological Data. Geomorphology, 276, 257-279.

Submit or recommend next manuscript to SCIRP and we will provide best service for you:

Accepting pre-submission inquiries through Email, Facebook, LinkedIn, Twitter, etc. A wide selection of journals (inclusive of 9 subjects, more than 200 journals)

Providing 24-hour high-quality service

User-friendly online submission system

Fair and swift peer-review system

Efficient typesetting and proofreading procedure

Display of the result of downloads and visits, as well as the number of cited articles

Maximum dissemination of your research work

Submit your manuscript at: http://papersubmission.scirp.org/

Or contact gep@scirp.org 